\title{
Loss in tocopherols and oxidative stability during the frying of frozen cassava chips
}

\author{
By Mara S. Corsini ${ }^{1}$, Marta G. Silva ${ }^{2}$ and Neuza Jorge ${ }^{1 *}$
}

\author{
1 Food Technology and Engineering Department - São Paulo State University. Rua Cristóvão \\ Colombo, 2265 - Jardim Nazareth. CEP 15054-000 - São José do Rio Preto - São Paulo - Brasil. \\ 2 Instituto de Tecnologia de Alimentos. Avenida Brasil, 2880. Caixa Postal 139. CEP 13070-178 - \\ Campinas - São Paulo - Brasil. \\ * Corresponding author: njorge@ibilce.unesp.br
}

\section{RESUMEN}

Pérdida de tocoferoles y estabilidad oxidativa durante la fritura de palitos de mandioca congelados.

El objetivo de este trabajo fue analizar los cambios en la concentración de tocoferoles y la evolución de la alteración oxidativa en aceites vegetales utilizados en fritura discontinua. La fritura de palitos de mandioca congelados fue realizada en una freidora eléctrica doméstica, en la cual el aceite fue calentando a $180^{\circ} \mathrm{C}$, durante 25 horas, con reposición de aceite fresco. Los resultados obtenidos de las determinaciones analíticas fueron sometidos a análisis de variancia, en esquema factorial para determinar la influencia de los factores aceite y tiempo de fritura sobre las alteraciones en los aceites. Los resultados muestran que las menores alteraciones ocurren para el aceite de palma, más saturado. Para los aceites de algodón y girasol, más insaturados, se verificó que, conforme disminuyó la concentración de tocoferoles, disminuye la estabilidad oxidativa.

PALABRAS-CLAVE: Aceites vegetales - Antioxidante Estabilidad oxidativa - Tocoferoles.

\section{SUMMARY}

Loss in tocopherols and oxidative stability during the frying of frozen cassava chips.

The present study was aimed at verifying tocopherols losses and oxidative stability changes in vegetable oils used in discontinuous frying. The frying of frozen cassava chips was carried out in a household electric frying pan, where the oil was heated to a temperature of $180^{\circ} \mathrm{C}$ for 25 hours, with fresh oil replacement. The results obtained from the analytical determinations were submitted to variance analysis, in a factorial scheme, using a completely randomized design, making it possible to determine the influence of the type of oil and frying times on changes in the oil. The data show that the smallest changes occur in palm oil, which is more saturated. For sunflower and cottonseed oils, which are more unsaturated, there was a clear decrease in both tocopherol concentration and oxidative stability.

KEY-WORDS: Antioxidants - Oxidative stability - Tocopherols - Vegetable oils.

\section{INTRODUCTION}

A significant part of edible oils and fats in the human diet are consumed after having been submitted to high temperatures in frying processes. Deep frying is the fastest method for cooking foods due to the two main characteristics of the process: high temperature and rapid heat transfer. The acceptance of fried, processed foods is universal, and appreciated by different ethnical groups (Sanibal and Mancini-Filho, 2002).

During the frying process, when the temperature is very high, the atmospheric oxygen may react with the superficial layer of the oil and produce oxidative changes. Oxidation is a degradative process that takes place when the atmospheric oxygen or the oxygen which is dissolved in the oil, reacts with the unsaturated fatty acids. The chemical reactions involved in the oil oxidation process are highly complex and, bring forth, in their most advanced stages, products which are unacceptable to consumers (Lima and Gonçalves, 1995).

The intake of thermally altered oils and fats represents a source of substances potentially toxic in a diet. The consumption of heated or oxidized oils involves possible health risks such asarteriosclerosis predisposition, mutagenic or carcinogenic actions. (Kubow, 1990).

Over recent years, researchers have made use of more sophisticated approaches and a combination of analytical techniques that enable them to determine the level of change as well as the quantification of the specific compounds produced in the oil during frying (Pozo-Díez et al., 1995; Del Ré and Jorge, 2006; Steel et al., 2006).

A way of monitoring the oil quality during the frying process is by determining the antioxidant concentration in the oils, mainly the tocopherols, which are used to prevent oxidation (Jorge, 1997).

Studying the tocopherol fraction as well as other unsaponifiable constituents in vegetable oils is a tool for the identification, characterization, and monitoring of the changes in oils and fats.

The purpose of the present study was to verify the relationship between the changes in tocopherol concentration and the evolution of the oxidative changes in vegetable oils used in discontinuous frying. 


\section{MATERIALS AND METHODS}

\subsection{Frying process}

Three types of oil were used for the discontinuous frying essays: refined cottonseed oil (RCO), refined sunflower oil (RSO) and refined palm oil (RPO). The cottonseed, sunflower and palm oils presented the following antioxidants in their compositions: tert butyl hydroquinone (TBHQ) and citric acid; citric acid; and TBHQ, citric acid and methyl silicon, respectively.

The frozen cassava chip discontinuous frying essays were carried out in an electric frying pan, Brand NKS home - Model DF-150/AL, with 1.5 liters of total capacity and a surface /oil volume ratio of $0.2 \mathrm{~cm}^{-1}$.

Fifty batches of cassava were fried at a controlled temperature of $180^{\circ} \mathrm{C} \pm 5^{\circ} \mathrm{C}$, regardless of the oil type, with approximately 250 grams of frozen cassava chips per batch, for five hours/day, during 5 consecutive days.

During the discontinuous frying process, intervals of 30 minutes were used to reheat the oil. At the end of each day the oil was filtered. In the complete experiment, a total of $1,650 \mathrm{~mL}$ of cottonseed oil; $1,800 \mathrm{~mL}$ of sunflower oil, and 1,850 $\mathrm{mL}$ of palm oil were added to keep the frying pan level constant.

Oil samples of $50 \mathrm{~mL}$ were collected at different time intervals: initial sample - at the end of the first and at every five frying sessions, namely, at $0 ; 0.5$; $2.5 ; 5 ; 7.5 ; 10 ; 12.5 ; 15 ; 17.5 ; 20 ; 22.5$ and 25 hours. Afterwards, the samples were stored at approximately $-20^{\circ} \mathrm{C}$ until analysis.

\subsection{Analytical determinations}

Tocopherols. The method AOCS Ce-89 (1996) was applied to determine tocopherol concentrations. The analysis was carried out by liquid chromatography with fluorescence detector (TSP brand and FL 2000 model). The following conditions were applied: silica column 60 with $25 \times 0.4 \mathrm{~cm}$ dimensions and $5 \mathrm{~mm}$ particles, $1.5 \mathrm{~mL} / \mathrm{min}$ flow and excitation wavelength of $292 \mathrm{~nm}$ with emission at $326 \mathrm{~nm}$. The mobile phase consisted of a mixture of $98.6 \%$ n-hexane, $1.2 \%$ ethyl acetate and $0.2 \%$ isopropanol, all of purity degree for HPLC. The calculations were performed using the four tocoferol isomers as external standards.

Oxidative stability index. Oil stability was measured following the AOCS standard method $\mathrm{Cd}$ 12b-92 (AOCS, 1996). The Rancimat equipment, METROHM brand, 743 model, was used, under the following conditions: 3 grams oil, $100^{\circ} \mathrm{C}$ and $20 \mathrm{~L} / \mathrm{h}$ air flow.

Total polar compounds. The method is based on the separation of the oil sample, using adsorption chromatography, into two fractions of different polarity that can be determined gravimetrically. The chromatographic method proposed by Dobarganes et al. (2000) was used.
Fatty acid composition, peroxide value and conjugated dienes. For these analyses, the AOCS standard methods were applied (AOCS, 1996).

\subsection{Statistical design}

Results were submitted to a variance analysis, in the completely randomized design, to determine the influence of the factors on the changes in the oils heated at high temperatures, in two replicates (Gomes, 2000).

For the tocopherols the statistical design was a factorial scheme $3 \times 6$, with 3 oil types (RCO, RSO and RPO) and 6 frying times $(0,5,10,15,20$ and 25 hours). With regards to the results obtained from the oxidative stability measurements, they were analyzed in a factorial scheme $3 \times 12$, with 3 oil types (RCO, RSO and RPO) and 12 frying times $(0,0.5$, 2.5, 5, 7.5, 10, 12.5, 15, 17.5, 20, 22.5 and 25 hours). For the variance analysis and the Tukey tests for the means at $p<5 \%$, the ESTAT program - System for Statistical Analysis, version 2.0 was used.

\section{RESULTS AND DISCUSSION}

Table 1 summarizes the characteristics of the initial oils. Fatty acid composition is one of the variables of interest in the frying process as the relationship between susceptibility to degradation and the degree of oil unsaturation has been well established (Jorge et al., 1996a, 1996b). In this study, the cottonseed and sunflower oils presented higher contents of polyunsaturated fatty acids, namely, 52.80 and $60.67 \%$, while the palm oil presented a higher content of saturated fatty acids (48.21\%).

Table 1

Characterization of the initial oils used in the frying of frozen cassava chips

\begin{tabular}{lccc}
\hline \multicolumn{1}{c}{ Characteristics } & RCO & RSO & RPO \\
\hline Fatty Acids (\%) & & & \\
Saturated & 28.04 & 11.03 & 48.21 \\
Monounsaturated & 16.78 & 27.23 & 42.39 \\
Polyunsaturated & 52.80 & 60.67 & 8.89 \\
Omega 3 & 0.12 & 0.19 & 0.22 \\
Trans & $<0.01$ & $<0.01$ & $<0.01$ \\
NI & 2.36 & 1.08 & 0.55 \\
Peroxide Index (meq/kg) & 3.20 & 3.40 & 0.5 \\
Conjugated Dienes (\%) & 1.33 & 0.51 & 0.28 \\
\hline
\end{tabular}

RCO - refined cottonseed oil, RSO - refined sunflower oil, RPO refined palm oil.

$\mathrm{NI}$ - Not identified.

\subsection{Tocopherol concentration}

The changes in tocopherol concentrations and in the corresponding vitamin $\mathrm{E}$ quantity are shown in Table 2. The initial values found for sunflower and 
cottonseed oils were in agreement with the values established by AOCS (1996). As for palm oil, the composition was close to that found by Yuki and Ishikawa (1976) and Dionisi et al. (1995).

Regarding the changes in tocopherol concentrations with the number of frying operations, as expected, a significant decrease was observed in sunflower and cottonseed oils as frying time increased. For the cottonseed oil, the loss in $\gamma$ tocopherol at the end of the experiment was higher $(48.43 \%)$ than that found for $\alpha$-tocopherol, $(39.27 \%)$. In contrast, in sunflower oil, $\alpha$-tocopherol had the highest degradation $(52.73 \%)$ while the smallest loss corresponded to the $\delta$-tocopherol $(25.45 \%)$. Regarding palm oil, the loss in $\alpha$ and $\beta$-tocopherols during frying was very small, 8.0 and $4.8 \%$, respectively, while $\gamma$ and $\delta$-tocopherols remained practically constant.

From the results presented in Table 2, it can be deduced that the total tocopherol degradation as well as the loss in vitamin E content of the oils was the highest for sunflower oil, approximately $52 \%$, and the lowest for e palm oil, roughly $8 \%$. Jorge and
Gonçalves (1998) studied the behavior of conventional sunflower oil and reported that the $\alpha$-tocopherol concentration decreased about $80 \%$ after six hours heating in discontinuous frying. They also observed that even with this significant degradation, $100 \mathrm{mg} / \mathrm{kg} \alpha$-tocopherol remained at the end of the frying sessions.

Results from studies of other groups vary significantly due to the high number of variables acting in the frying process and even to unknown, unforeseen and uncontrolled variables (Rodrigues Machado et al., 2007). Thus, Barrera-Arellano et al. (2002) verified that after heating at $180^{\circ} \mathrm{C}$, tocopherol degradation occurred regardless of the oil type. Nevertheless, they observed that after 10 hours heating, significant total tocopherol quantities still remained in polyunsaturated oils such as sunflower, soybean and canola oils, whereas in monounsaturated oils, palm olein, high oleic sunflower oil and olive oil, the presence of tocopherols was not detected. Also, Yuki and Ishikawa (1976) reported that soybean oil containing $668 \mathrm{mg} / \mathrm{kg}$ total tocopherol lost $80.2 \%$ of tocopherols

Table 2

Loss in tocopherols $(\mathrm{mg} / 100 \mathrm{~g})$ during the frying of frozen cassava chips

\begin{tabular}{|c|c|c|c|c|c|c|}
\hline \multirow{2}{*}{ Oils } & \multicolumn{6}{|c|}{ Frying Times (hours) } \\
\hline & 0 & 5 & 10 & 15 & 20 & 25 \\
\hline $\begin{array}{l}\alpha \text {-tocopherol } \\
\mathrm{RCO} \\
\mathrm{RSO} \\
\mathrm{RPO}\end{array}$ & $\begin{array}{l}43.21^{\mathrm{aB}} \\
70.96^{\mathrm{aA}} \\
11.50^{\mathrm{aC}}\end{array}$ & $\begin{array}{c}36.46^{\mathrm{abB}} \\
54.50^{\mathrm{bA}} \\
12.50^{\mathrm{aC}}\end{array}$ & $\begin{array}{c}31.29^{\mathrm{bcB}} \\
43.66^{\mathrm{cA}} \\
13.42^{\mathrm{aC}}\end{array}$ & $\begin{array}{c}25.36^{\mathrm{cdB}} \\
40.49^{\mathrm{cdA}} \\
13.20^{\mathrm{aC}}\end{array}$ & $\begin{array}{l}23.07^{\mathrm{dB}} \\
36.20^{\mathrm{dA}} \\
13.55^{\mathrm{aC}}\end{array}$ & $\begin{array}{c}26.24^{\mathrm{cdB}} \\
33.54^{\mathrm{dA}} \\
10.58^{\mathrm{aC}}\end{array}$ \\
\hline $\begin{array}{l}\beta \text {-tocopherol } \\
\text { RCO } \\
\text { RSO } \\
\text { RPO }\end{array}$ & $\begin{array}{l}3.54^{\mathrm{aA}} \\
2.66^{\mathrm{aB}} \\
0.42^{\mathrm{aC}}\end{array}$ & $\begin{array}{l}3.02^{\mathrm{bA}} \\
2.15^{\mathrm{bB}} \\
0.55^{\mathrm{aC}}\end{array}$ & $\begin{array}{l}3.13^{\mathrm{abA}} \\
1.99^{\mathrm{bcB}} \\
0.48^{\mathrm{ac}}\end{array}$ & $\begin{array}{c}1.94^{\mathrm{cA}} \\
1.77^{\mathrm{bcdA}} \\
0.48^{\mathrm{aB}}\end{array}$ & $\begin{array}{c}1.68^{\mathrm{cA}} \\
1.59^{\mathrm{cdA}} \\
0.46^{\mathrm{aB}}\end{array}$ & $\begin{array}{l}1.99^{\mathrm{cA}} \\
1.50^{\mathrm{dB}} \\
0.40^{\mathrm{aC}}\end{array}$ \\
\hline $\begin{array}{l}\text {-tocopherol } \\
\text { RCO } \\
\text { RSO } \\
\text { RPO }\end{array}$ & $\begin{array}{c}25.85^{\mathrm{aA}} \\
1.86^{\mathrm{aB}} \\
0.02^{\mathrm{aC}}\end{array}$ & $\begin{array}{c}22.87^{\mathrm{bA}} \\
1.52^{\mathrm{aB}} \\
0.02^{\mathrm{aC}}\end{array}$ & $\begin{array}{c}20.15^{\mathrm{cA}} \\
1.38^{\mathrm{aB}} \\
0.02^{\mathrm{aC}}\end{array}$ & $\begin{array}{c}17.54^{\mathrm{dA}} \\
1.19^{\mathrm{aB}} \\
0.02^{\mathrm{aC}}\end{array}$ & $\begin{array}{c}15.38^{\mathrm{eA}} \\
0.99^{\mathrm{aB}} \\
0.02^{\mathrm{aB}}\end{array}$ & $\begin{array}{l}13.33^{\mathrm{fA}} \\
0.91^{\mathrm{aB}} \\
0.02^{\mathrm{aB}}\end{array}$ \\
\hline 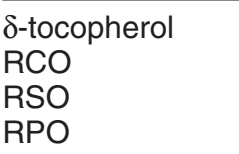 & $\begin{array}{l}0.32^{\mathrm{aB}} \\
0.55^{\mathrm{aA}} \\
0.02^{\mathrm{aC}}\end{array}$ & $\begin{array}{c}0.30^{\mathrm{aB}} \\
0.48^{\mathrm{abA}} \\
0.02^{\mathrm{aC}}\end{array}$ & $\begin{array}{l}0.27^{\mathrm{abB}} \\
0.45^{\mathrm{bA}} \\
0.02^{\mathrm{aC}}\end{array}$ & $\begin{array}{l}0.24^{\mathrm{abB}} \\
0.42^{\mathrm{bA}} \\
0.02^{\mathrm{aC}}\end{array}$ & $\begin{array}{l}0.18^{\mathrm{bB}} \\
0.41^{\mathrm{bA}} \\
0.02^{\mathrm{aC}}\end{array}$ & $\begin{array}{l}0.19^{\mathrm{bB}} \\
0.41^{\mathrm{bA}} \\
0.02^{\mathrm{aC}}\end{array}$ \\
\hline $\begin{array}{l}\text { Total tocopherol } \\
\text { RCO } \\
\text { RSO } \\
\text { RPO }\end{array}$ & $\begin{array}{l}73.23^{\mathrm{aA}} \\
76.01^{\mathrm{aA}} \\
11.91^{\mathrm{aB}}\end{array}$ & $\begin{array}{l}62.97^{\mathrm{bA}} \\
58.63^{\mathrm{bA}} \\
13.04^{\mathrm{aB}}\end{array}$ & $\begin{array}{l}54.98^{\mathrm{cA}} \\
47.44^{\mathrm{cB}} \\
13.96^{\mathrm{aC}}\end{array}$ & $\begin{array}{c}44.07^{\mathrm{dA}} \\
43.86^{\mathrm{cdA}} \\
13.69^{\mathrm{aB}}\end{array}$ & $\begin{array}{l}39.87^{\mathrm{dA}} \\
38.53^{\mathrm{dA}} \\
14.00^{\mathrm{aB}}\end{array}$ & $\begin{array}{l}41.89^{\mathrm{dA}} \\
36.41^{\mathrm{dA}} \\
10.98^{\mathrm{aB}}\end{array}$ \\
\hline $\begin{array}{l}\text { Vitamina } E^{*} \\
\text { RCO } \\
\text { RSO } \\
\text { RPO }\end{array}$ & $\begin{array}{l}52.50^{\mathrm{aB}} \\
78.75^{\mathrm{aA}} \\
12.50^{\mathrm{aC}}\end{array}$ & $\begin{array}{l}44.00^{\mathrm{bB}} \\
60.75^{\mathrm{bA}} \\
14.00^{\mathrm{aC}}\end{array}$ & $\begin{array}{c}38.25^{\mathrm{bcB}} \\
49.00^{\mathrm{cA}} \\
14.75^{\mathrm{ac}}\end{array}$ & $\begin{array}{c}31.00^{\mathrm{cdB}} \\
45.25^{\mathrm{cdA}} \\
15.00^{\mathrm{aC}}\end{array}$ & $\begin{array}{c}28.00^{\mathrm{dB}} \\
39.75^{\mathrm{deA}} \\
14.75^{\mathrm{aC}}\end{array}$ & $\begin{array}{c}31.00^{\mathrm{cdB}} \\
37.50^{\mathrm{eA}} \\
11.50^{\mathrm{aC}}\end{array}$ \\
\hline $\begin{array}{l}\text { Vitamina } E^{* *} \\
\text { RCO } \\
\text { RSO } \\
\text { RPO }\end{array}$ & $\begin{array}{l}47.71^{\mathrm{aB}} \\
71.94^{\mathrm{aA}} \\
11.43^{\mathrm{aC}}\end{array}$ & $\begin{array}{l}40.41^{\mathrm{bB}} \\
55.29^{\mathrm{bA}} \\
12.65^{\mathrm{aC}}\end{array}$ & $\begin{array}{c}34.90^{\mathrm{bcB}} \\
44.38^{\mathrm{cA}} \\
13.55^{\mathrm{aC}}\end{array}$ & $\begin{array}{c}28.31^{\mathrm{cdB}} \\
41.13^{\mathrm{cdA}} \\
13.49^{\mathrm{aC}}\end{array}$ & $\begin{array}{l}25.44^{\mathrm{dB}} \\
36.79^{\mathrm{dA}} \\
13.67^{\mathrm{aC}}\end{array}$ & $\begin{array}{c}28.62^{\mathrm{cdA}} \\
34.08^{\mathrm{dA}} \\
10.54^{\mathrm{aB}}\end{array}$ \\
\hline
\end{tabular}

RCO - refined cottonseed oil, RSO - refined sunflower oil, RPO - refined palm oil.

$a, b$. (row) - For each oil, values followed by the same lower case letters, do not differ significantly $(p>0.05)$.

A, B. (column) - For each frying time, values followed by the same capital letters, do not differ significantly $(p>0.05)$.

${ }^{*}$ Vitamin E expressed in Ul/100g, ${ }^{* *}$ Vitamin E expressed as $\alpha$-tocopherol in $\mathrm{mg} / 100 \mathrm{~g}$ 
when submitted to thermal oxidation conditions for 10 hours at approximately $180^{\circ} \mathrm{C}$.

In order to evaluate the influence of the type of oil and the frying time on $\alpha$-tocopherol, $\beta$-tocopherol, $\gamma$-tocopherol, $\delta$-tocopherol, total tocopherol, vitamin $E$, and vitamin $\mathrm{E}$ expressed as $\alpha$-tocopherol, variance analysis calculations were useful. The results have been also included in Table 2 .

In summarizing the statistical analysis of the differences found, the following aspects stand out:

a. Significant differences were found in cottonseed and sunflower oils for the loss in major tocopherols, i. e. $\alpha$-tocopherol in both oils and $\gamma$ tocopherol in cottonseed oil, throughout the heating time, although no differences were found for any of the heating periods for palm oil.

b. Total tocopherol values decreased along the frying times with no significant difference at 15 hours frying for cottonseed oil, and from 10 hours frying onwards, for sunflower oil. However, for palm oil, the total tocopherol values remained practically constant with no significant difference throughout the frying times.

c. Regarding the oils, significant differences were found for total tocopherol concentration between the three oils at 10 hours. At the other frying times, the total tocopherol concentrations for cottonseed and sunflower oils did not differ significantly, but did differ significantly from palm oil whose values were much lower.

\subsection{Oxidative stability index}

Table 3 shows the results obtained for the oxidative stability of the oils throughout the frying period. The high oxidative stability of the initial palm oil (141.34 hours) can be pointed out, followed by cottonseed (26.17 hours), and sunflower (10.43 hours) oils. These differences were expected given

Table 3

Loss in oxidative stability (hours at $100^{\circ} \mathrm{C}$ ) during the frying of frozen cassava chips

\begin{tabular}{cccc}
\hline $\begin{array}{c}\text { Frying } \\
\text { Times (hours) }\end{array}$ & $\begin{array}{c}\text { Cottonseed } \\
\text { oil }\end{array}$ & $\begin{array}{c}\text { Sunflower } \\
\text { oil }\end{array}$ & $\begin{array}{c}\text { Palm } \\
\text { oil }\end{array}$ \\
\hline 0 & $26.17^{\mathrm{aB}}$ & $10.43^{\mathrm{aC}}$ & $141.34^{\mathrm{aA}}$ \\
0.5 & $21.97^{\mathrm{aB}}$ & $8.90^{\mathrm{aC}}$ & $134.09^{\mathrm{bA}}$ \\
2.5 & $14.52^{\mathrm{bB}}$ & $7.55^{\mathrm{aC}}$ & $119.51^{\mathrm{cA}}$ \\
5 & $12.39^{\mathrm{bB}}$ & $7.60^{\mathrm{aC}}$ & $110.86^{\mathrm{defA}}$ \\
7.5 & $12.29^{\mathrm{bB}}$ & $7.41^{\mathrm{aC}}$ & $104.96^{\mathrm{fgA}}$ \\
10 & $11.97^{\mathrm{bB}}$ & $7.75^{\mathrm{aB}}$ & $106.21^{\text {efgA }}$ \\
12.5 & $12.26^{\mathrm{bB}}$ & $7.06^{\mathrm{aC}}$ & $104.64^{\mathrm{gA}}$ \\
15 & $11.20^{\mathrm{bB}}$ & $7.74^{\mathrm{aB}}$ & $104.04^{\mathrm{gA}}$ \\
17.5 & $11.02^{\mathrm{bB}}$ & $7.33^{\mathrm{aB}}$ & $109.50^{\text {efgA }}$ \\
20 & $10.59^{\mathrm{bB}}$ & $7.28^{\mathrm{aB}}$ & $112.38^{\mathrm{deA}}$ \\
22.5 & $10.43^{\mathrm{bB}}$ & $7.51^{\mathrm{aB}}$ & $110.96^{\mathrm{defA}}$ \\
25 & $10.49^{\mathrm{bB}}$ & $7.30^{\mathrm{aB}}$ & $116.69^{\mathrm{cdA}}$ \\
\hline
\end{tabular}

a, b ... (column) - For each oil, values followed by the same lower case letters, do not differ significantly $(p>0.05)$.

A, B ... (row) - For each frying time, values followed by the same capital letter, do not differ significantly $(p>0.05)$. that auto-oxidation is a process which occurs between molecular oxygen and unsaturated fatty acids and, consequently, oxidative stability is intrinsically related to the unsaturation degree of the oil. Jorge et al. (1996a) and Barrera-Arellano et al. (2002), when analyzing the initial oxidative stability of sunflower oil found similar values to the ones presented in this study -9.0 and 9.9 hours, respectively. With respect to palm and cottonseed oil, it is important to note that the oils used in this study contain TBHQ as an added antioxidant and the values may be higher than those found for refined oils without additives.

As observed in the table, oxidative stability values decreased as frying time increased. However, the significance of the differences established by means of the variance analysis for the frying times was unexpected. For example, for sunflower oil there were no significant differences in the stability values throughout the frying period in spite of the loss in tocopherols mentioned above. In contrast, refined palm oil, with a low loss in tocopherols, showed an unstable behavior throughout the frying times. It can be observed that the oxidative stability values kept decreasing up to 15 hours of frying, showing significant difference during the first 5 hours.

As for the oils, there were significant differences for the oxidative stability values among the three oils for $0,0.5,2.5,5,7.5$ and 12.5 hours frying times. At the other frying times, there was no significant difference between cottonseed and sunflower oils, but both differed significantly from refined palm oil which presented the highest oxidative stability at all the frying times.

In a study to assess the degradation state of soybean oil used in a frying system of a university restaurant, where 5,000 meal servings are supplied daily, Lima and Gonçalves (1994) verified that during the frying process studied, 44 hours at $180^{\circ} \mathrm{C}$ temperature, the oxidative stability of the oil remained practically constant as opposed to what was observed in the present study. Nevertheless, this behavior may be justified by the fact that when different foods such as chicken, meat balls or beef are fried in the same oil, the changes in stability become unforeseeable due to the fact that the lipids from the foods are solubilized in the frying oil modifying its fatty acid composition as well as its antioxidant and prooxidant contents.

The results obtained regarding oxidative stability, indicate that among the oils studied, palm oil, due to its lower degree of unsaturation, presents the highest oxidative stability throughout the frying process and also the lowest percent stability loss after 25 hours of frying. The combination of carotenoids, tocopherols and tocotrienols and the high percentage of saturated fatty acids (approximately $50 \%$ ) give palm oil a higher oxidative stability when compared to other vegetable oils.

In principle, it was expected that cottonseed oil would be more resistant to oxidation than sunflower oil, because of its lower degree of unsaturation and its lower loss in tocopherols. Surprisingly, the loss in 
oxidative stability occurred in a higher proportion than for sunflower oil.

\subsection{Total polar compounds}

Table 4 shows the average results of polar compounds for different vegetable oils at the beginning and at the end of the frying process. As can be observed, the percentage of polar compounds increased significantly throughout the frying process for both cottonseed and sunflower oils. This increase in polar compounds is related to the loss in tocopherols and oxidative stability previously mentioned. As for palm oil, the increase in polar compounds was minimal not only due to its low degree of unsaturation but mainly to the presence of silicon oil as additive. As reported previously, the addition of silicon oil drastically decreases the oil degradation and the loss in tocopherol (Jorge et al., 1996b).

Table 4

Initial and final contents of polar compounds (wt \% on oil) in the frying of frozen cassava chips

\begin{tabular}{cccc}
\hline $\begin{array}{c}\text { Frying Times } \\
\text { (hours) }\end{array}$ & $\begin{array}{c}\text { Cottonseed } \\
\text { oil }\end{array}$ & $\begin{array}{c}\text { Sunflower } \\
\text { oil }\end{array}$ & $\begin{array}{c}\text { Palm } \\
\text { oil }\end{array}$ \\
\hline 0 & $5.32^{\mathrm{bA}}$ & $2.41^{\mathrm{bB}}$ & $5.32^{\mathrm{aA}}$ \\
25 & $15.17^{\mathrm{aA}}$ & $14.20^{\mathrm{aA}}$ & $6.85^{\mathrm{aB}}$ \\
\hline
\end{tabular}

a, b (column) - For each oil, values followed by the same lower case letters, do not differ significantly $(p>0.05)$.

$A$, B (row) - For each frying time, values followed by the same capital letter, do not differ significantly $(p>0.05)$.

\section{CONCLUSIONS}

Oil degradation as expressed by the percentages of polar compounds, clearly depended on the degree of unsaturation of the oils.

The minimum loss in stability and tocopherols were found for the oil with the lowest degree of unsaturation.

Changes in oxidative stability were not parallel to the loss in tocopherols revealing the difficulties involved in frying and the existence of uncontrolled variables in the process.

\section{ACKNOWLEGEMENTS}

The authors want to thank Agropalma Amazonia Refining Company, for the donation of the refined palm oil, and to the company, DeMarch Ind. e Com. de Frutas Ltda, for the frozen cassava chips supply.

\section{REFERENCES}

AOCS. 1996. Official Methods and Recommended Practices of the American Oil Chemists' Society. Champaign. Ed. Atual.
Barrera-Arellano D, Ruiz-Méndez MV, Velasco J, Márquez-Ruiz G, Dobarganes MC. 2002. Loss of tocopherols and formation of degradation compounds at frying temperatures in oils differing in degree of unsaturation and natural antioxidants content. J. Sci. Food Agric. 82, 1696-1702.

Del Ré P, Jorge N. 2006. Comportamento de óleos vegetais em frituras descontínuas de produtos préfritos congelados. Ciênc. Tecnol. Aliment. 26, 56-63.

Dionisi F, Prodolliet J, Tagliaferri E. 1995. Assessment of olive oil adulteration by reversed-phase highperformance liquid chromatography /amperometric detection of tocopherols and tocotrienols. J. Am. Oil Chem. Soc. 72, 1505-1511.

Dobarganes MC, Velasco J, Dieffenbacher A. 2000. Determination of polar compounds, polymerized and oxidized triacylglycerols, and diacylglycerols in oils and fats. Pure Appl. Chem. 72, 1563-1575.

Gomes FP. 2000. Statistical experiment course. Piracicaba: Nobel, 477 p.

Jorge N, Gonçalves LAG. 1998. Comportamento do óleo de girassol com alto teor de ácido oléico em termoxidação e fritura. Ciênc. Tecnol. Aliment. 18, 335-342.

Jorge N. 1997. Alterações em óleos de fritura. Hig. Aliment. 11, 15-22.

Jorge N, Márquez-Ruiz G, Martín-Polvillo M, RuizMéndez MV Dobarganes MC. 1996a. Influence of dimethylpolysiloxane addition to edible oils: dependance on the main variables of the frying process. Grasas y Aceites 47,14-19.

Jorge N, Márquez-Ruiz G, Martín-Polvillo M, RuizMéndez MV, Dobarganes MC. 1996b. Influence dimethylpolyxilosane addition to frying oils: Performance of sunflower oils in discontinuous and continuous laboratory frying. Grasas y Aceites 47, 2025.

Kubow S. 1990. Toxicity of dietary lipid peroxidation products. Trends Food Sci. Technol. 1, 67-71.

Lima JR, Gonçalves LAG. 1994. Parâmetros de avaliação da qualidade de óleo de soja utilizado para fritura. Quím. Nova 17, 392-396.

Lima JR, Gonçalves LAG. 1995. Avaliação analítica de óleos utilizados em processo de fritura. Bol. SBCTA 29, 186-192.

Pozo-Díez RM, Masoud-Musa TA, Pérez-Camino MC, Dobarganes MC. 1995. Intercambio lipídico durante la fritura de patatas prefritas congeladas en aceite de girasol alto oleico. Grasas y Aceites 46, 85-91.

Rodrigues Machado ES, Marmesat S, Abrantes S, Dobarganes MC. 2007. Uncontrolled variables in frying studies: differences in repeatability between thermoxidation and frying experiments. Grasas $y$ Aceites 58, 283-288.

Sanibal EAA, Mancini-Filho J. 2002. Alterações físicas, químicas e nutricionais de óleos submetidos ao processo de fritura. Food Ingred. South Am. 18, 64-71.

Steel CJ, Dobarganes MC, Barrera-Arellano D. 2006. Formation of polymerization compounds during thermal oxidation of cottonseed oil, partially hydrogenated cottonseed oil and their blends. Grasas y Aceites 57, 284-291.

Yuki E, Ishikawa Y. 1976. Tocopherol contents of nine vegetable frying oils, and their changes under simulated deep-fat frying conditions. J. Am. Oil Chem. Soc. 53, 673-676. 